\title{
INFLUENCE OF VESSEL TYPE, PHYSICAL STATE OF MEDIUM AND TEMPORARY IMMERSION ON THE MICROPROPAGATION OF THREE Rhodophiala SPECIES
}

\author{
Manuel Muñoz ${ }^{1}$, Peter Seemann ${ }^{1}$, Gloria Jara $^{1}$, and Ricardo Riegel ${ }^{1}$
}

\begin{abstract}
Rhodophiala C. Presl (Amaryllidaceae) is a genus of attractive flowering geophytes native to South America. They have ornamental value, but most species are not well- known and have conservation problems. The objective of this study was to optimize a micropropagation process to support the use and preservation of three Chilean native species, R. montana (Phil.) Traub, R. splendens (Rengifo) Traub., and R. ananuca (Phil.) Traub. The research evaluated the feasibility of implementing liquid medium culture and assessed the influence of different tissue culture systems on the shoot production and biomass increment of small bulbs. Three experiments were carried out. The first one determined the influences of flask size and volume of media; the second compared liquid and solid media, and in the third experiment, a temporary immersion system (TIS), and conventional culture in static liquid, shaken liquid and gelled Murashige and Skoog (MS) media were compared. By using larger (350 mL) flasks with higher (50 mL) media volume, $100 \%$ more fresh weight of microbulb was obtained that treatment with smaller flasks (45 mL) and media volume $(10 \mathrm{~mL})$. In gelled medium, hyperhydricity affected only $5 \%$ of explants, while in liquid medium was $16-40 \%$. Survival to acclimatization reached $87-94 \%$ for plants from gelled medium; from liquid medium only $38-69 \%$. TIS yielded higher propagation rate $(1.9$ shoots in $30 \mathrm{~d})$ compared with shaken liquid medium $(1.0)(\mathrm{P}<$ 0.05 ) in $R$. ananuca only. Current procedures are appropriate for the support of ex situ conservation and germplasm bank establishment.
\end{abstract}

Key words: TIS, liquid culture, micropropagation, acclimatization, Rhodophiala .

\section{INTRODUCTION}

The genus Rhodophiala C. Presl (Amaryllidaceae), native to South America, comprises 31 bulbous species (Traub, 1956). These wild-growing geophytic plants have high ornamental potential because of their attractive red, pink, yellow or orange flowers. However, most Rhodophiala species are vaguely known and grow only in restricted, isolated geographic areas. Furthermore, their survival is endangered because of habitat destruction (Schiappacasse et al., 2002).

For both commercial utilization and ex situ conservation a fast and efficient vegetative propagation system is needed. However, like other Amaryllidaceae,

'Universidad Austral de Chile, Facultad de Ciencias Agrícolas, Casilla 567, Valdivia, Chile. "Corresponding author

(mamunoz@uach.cl).

Received: 10 September 2008.

Accepted: 21 December 2008. vegetative multiplication by bulb offsets is very low (Schiappacasse et al., 2002; Angulo et al., 2003).

When small bulbs of $R$. bagnoldii are cultivated in vitro employing solid Murashige and Skoog (1962) (MS) medium, multiple shooting is obtained only when a slight incision in the basal plate is applied to the bulblets (Olate and Bridgen, 2005). It is also feasible to culture R.montana, $R$. splendens and $R$. ananuca in gelled MS medium, but the average multiplication rate is quite low ( 1.5 to 2 to 60 d) (Jara et al., 2005). The same authors confirmed that a slight incision in the basal plate of bulblets may induce new shoots, but with considerable variability in number between explants. Treatments with different combinations and concentrations of growth regulators, usually applied in other Amaryllidaceae, have not been successful in improving propagation rates (Jara et al., 2005). Therefore, different aspects of the micropropagation process must be adjusted to improve propagation rates, vitroplant quality and ex vitro viability. 
In conventional micropropagation processes, vessel type influences the in vitro performance of explants by a consequence of differences in microculture humidity and gaseous exchange. In some species, vessel size is a striking factor, greatly affecting microshoot quality and influencing shoot length and shoot number per explant (McClelland and Smith, 1990).

Gelled or liquid medium can drastically change the in vitro performance of explants, even when using the same medium formulation, because of differences in microculture humidity and nutrient availability. Even though liquid culture systems can generate some disorders, such as hyperhydricity, they generally encourage faster growth and propagation. Additionally, liquid media are more amenable to automation, as shown by several authors who used the temporary immersion system (TIS). TIS also has additional advantages such as promoting more uniform media and oxygen supply, decreasing apical dominance and stimulating lateral bud growth (Etienne and Berthouly, 2002; Adelberg, 2004; Zhu et al., 2005; Ruffoni and Savona, 2005; Ziv, 2005).

This study was focused on evaluating the feasibility of implementing liquid medium culture and on assessing the influence of different tissue culture systems on shoot production, bulb enlargement, hyperhydricity and browning of explants from $R$. montana, $R$. splendens and $R$. ananuca. Different types of flasks, solid or liquid media and TIS were used.

\section{MATERIALS AND METHODS}

Origin of plant material: Seeds of $R$. montana (collected from Laguna del Maule, Chile), R. splendens (from Vilches Alto, Chile) and $R$. ananuca (from Aguada de Tongoy, Chile) were entered into in vitro culture as described by Jara et al. (2005), germinated and kept in
MS medium with $30 \mathrm{~g} \mathrm{~L}^{-1}$ of sucrose, where microbulbs were formed.

\section{Influence of flask size and medium volume}

Microbulbs of $R$. montana and $R$. ananuca were wounded with an incision in the basal plate and cultivated in $45 \mathrm{~mL}$ flasks containing $10 \mathrm{~mL}$ MS liquid media with $30 \mathrm{~g} \mathrm{~L}^{-1}$ of sucrose without plant growth regulators (45/10, Table 1) and $350 \mathrm{~mL}$ flasks containing $50 \mathrm{~mL}$ of the same medium (350/50). In both treatments, a hydrophilic cotton disc was used as a support. A single explant was placed in each flask with 25 replicates per treatment. The cultures were kept at $22 \pm 2{ }^{\circ} \mathrm{C}$ under $50 \mu \mathrm{mol} \mathrm{m}{ }^{-2}$ $\mathrm{s}^{-1}$ of light (fluorescent white light Phillips TLT 40W/54 RS) for $60 \mathrm{~d}$ with a 16:8 h photoperiod. The variables evaluated were the number of shoots and the plant and bulb growth indices [(final weight - initial weight)/ initial weight]. Statistical analyses were performed by comparing the means through a Student's t test. A MannWhitney test was used for variables having a non-normal distribution. Abnormal plants showing translucent tissues of glassy appearance or brown tissue were classified as hyperhydric and browned individuals, respectively, statistical differences were assessed by Chi Square Test. The significance level for statistical analysis for this and all experiments in this study was $\mathrm{P}<0.05$.

After the experiment was concluded, the remaining nutrient content in the medium was analyzed. $\mathrm{N}^{-\mathrm{NO}_{3}}$ and $\mathrm{N}^{-\mathrm{NH}_{4}}$ were determinate by Kjeldahl method, $\mathrm{P}$ by molybdenum blue colorimetric method, $\mathrm{K}$ by spectrophotometry of atomic emission and $\mathrm{Mg}$ by spectrophotometry of atomic absorption.

\section{Micropropagation in liquid and gelled MS medium}

In order to determine the influence of liquid or solid medium on the in vitro performance of explants and their

Table 1. Number of shoots, microbulb growth, browning and hyperhydricity in vitro of Rhodophiala species cultured in two vessel types with different flask size and medium volume.

\begin{tabular}{|c|c|c|c|c|c|c|}
\hline Treatment & $\begin{array}{c}\text { Number } \\
\text { of shoots }\end{array}$ & $\begin{array}{c}\text { Plant growth } \\
\text { index }\end{array}$ & $\begin{array}{c}\text { Bulb growth } \\
\text { index }\end{array}$ & Bulb weight & $\begin{array}{l}\text { Browned } \\
\text { explants }\end{array}$ & $\begin{array}{c}\text { Hyperhydric } \\
\text { explants }\end{array}$ \\
\hline & & & & $\mathrm{g}$ & 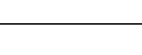 & \\
\hline \multicolumn{7}{|c|}{ R. montana } \\
\hline $45 / 10$ & $1.5 \pm 0.2$ & $5.7 \pm 0.7 b$ & $1.7 \pm 0.3 b$ & $0.6 \pm 0.1 b$ & $64 a$ & 7 \\
\hline $350 / 50$ & $2.1 \pm 0.4$ & $8.6 \pm 1.1 \mathrm{a}$ & $4.5 \pm 0.9 a$ & $1.2 \pm 0.1 \mathrm{a}$ & $13 b$ & 16 \\
\hline \multicolumn{7}{|c|}{ R. splendens } \\
\hline $45 / 10$ & $1.3 \pm 0.1$ & $7.1 \pm 1.5$ & $1.4 \pm 0.3 b$ & $0.5 \pm 0.1 b$ & 44 & 11 \\
\hline $350 / 50$ & $1.6 \pm 0.2$ & $8.3 \pm 1.5$ & $2.5 \pm 0.4 a$ & $1.0 \pm 0.9 \mathrm{a}$ & 17 & 14 \\
\hline
\end{tabular}

Different letters indicate statistical differences $(\mathrm{P}<0.05)$ between treatments within species only. If letters are not displayed, this indicate no significant differences. Values correspond to mean \pm standard error.

45/10: $45 \mathrm{~mL}$ flasks with $10 \mathrm{~mL}$ Murashige and Skoog (MS) liquid media; 350/50: $350 \mathrm{~mL}$ flasks with $50 \mathrm{~mL}$ MS liquid media. $R$. ananuca was not included in this experiment due to unavailability of plant material. 
subsequent acclimatization, two treatments were carried out.

Microbulbs of $R$. montana, $R$. splendens and $R$. ananuca with an incision in the basal plate were cultivated in $350 \mathrm{~mL}$ flasks with $50 \mathrm{~mL}$ of liquid MS medium supplemented with $30 \mathrm{~g} \mathrm{~L}^{-1}$ of sucrose, without plant growth regulators, with a hydrophilic cotton disc as a support, or in the same type of flask with $50 \mathrm{~mL}$ gelled (8 $\mathrm{g} \mathrm{L}^{-1}$ agar Fluka Chemie AG, Buchs, Switzerland) MS medium plus sucrose. A single explant was placed in each flask, with 20 replicates per treatment. Plants were kept at same conditions indicated earlier. Afterwards, the same variables as in the first experiment were evaluated. Additionally, a subset of five explants from each treatment was used for determining the proportion of dry matter (DM)

For the acclimatization experiment, explants were grown for $30 \mathrm{~d}$ inside closed plastic trays in peat/ sand substrate (1:1), fertilized with 50\% MS solution. A constant temperature of $22{ }^{\circ} \mathrm{C}$ and a $16 \mathrm{~h}$ day were maintained in the growth chamber. After that, the boxes were placed for another $30 \mathrm{~d}$ in a greenhouse with an average temperature of $21{ }^{\circ} \mathrm{C}\left(\min .12{ }^{\circ} \mathrm{C}\right.$; max. 29 ${ }^{\circ} \mathrm{C}$ ) with $15 \mathrm{~h}$ approximately of day length. Finally, the plants were placed into $1.5 \mathrm{~L}$ pots containing a soil/sand substrate (2:1), cultivated for 7 or 8 wk and fertilized every $15 \mathrm{~d}$ with a solution of $1 \mathrm{~g} \mathrm{~L}^{-1} \mathrm{KNO}_{3}$ and $1 \mathrm{~g} \mathrm{~L}^{-1}$ $\mathrm{NH}_{4} \mathrm{PO}_{4}$.

After each acclimatization step, survival (\%), plant weight $(\mathrm{g})$, plant growth index [(final weight of plant after three stages of acclimatization - initial weight ex vitro)/ initial weight ex vitro], and bulb diameter $(\mathrm{mm})$ were measured. Additionally, correlations between weight reached in vitro and ex vitro treatments were made.

Statistical analyses were performed by comparing the means through a Student's t test between results from liquid and gelled medium and subsequent acclimatization stages, for each species separately. A Mann-Whitney test was used for variables having a non-normal distribution. Chi square test was used to asses statistical differences on percentage of hyperhydric and browned explant and differences on survival to acclimatization.

\section{Comparing the temporary immersion system and conventional culture in static liquid, shaken liquid and gelled MS media}

In this experiment, six treatments were compared. The experimental unit was five micro bulbs each with an incision in the basal plate. In each treatment, three replicates of the experimental unit were used. The temporary immersion system (TIS) was of the "twinflasks" type (Figure 1A), based on the model described by Etienne and Berthouly (2002). Flasks were $18.2 \mathrm{~cm}$ tall and $8.5 \mathrm{~cm}$ wide. The influence of media volume on microbulb performance was tested using 20, 40 and $60 \mathrm{~mL}$ of medium per explant. The flooding height was $2.2,3.6$ and $5.3 \mathrm{~cm}$, respectively. In all three treatments, one immersion of 3 min every $12 \mathrm{~h}$ was programmed. The other three treatments consisted of conventional microbulb culture in static liquid media $(1000 \mathrm{~mL}$ flask $100 \mathrm{~mL}^{-1}$ of medium) with a hydrophilic cotton disc as support, liquid media (same flask type and volume) in orbital shaker (Unimax 2010, Heidolph Instruments, Schwabach, Germany, $100 \mathrm{rpm}$ ) and gelled media (same flask type and volume) in $8 \mathrm{~g} \mathrm{~L}^{-1}$ agar. In all cases, the culture medium was MS supplemented with $0.54 \mu \mathrm{M}$ naftalenacetic acid (NAA), $4.4 \mu \mathrm{M}$ 6-benzylaminopurine (BAP) and $30 \mathrm{~g} \mathrm{~L}^{-1}$ of sucrose. Experimental design was completely randomized.

After $30 \mathrm{~d}$, the same variables as in experiment one were evaluated using the ANOVA Test. Tukey test was performed for mean comparison. The data were calculated as percentages (hyperhydric and browned explants) and transformed with the arcsine function before carrying out the statistical test. In all cases, Statgraphics Plus 5.0 software was used.

\section{RESULTS AND DISCUSSION}

In the first experiment, for both Rhodophiala species tested, the utilization of larger flasks with a higher media volume (350/50) did not affect the number of shoots. Independent of treatment, only a few bulbs developed between 2 to 7 new shoots (Figure 1B and 1D). There was no relationship between explant weight and number of shoots $\left(\mathrm{P}=0.99 ; \mathrm{R}^{2}=0.0 \%\right)$. Treatment $350 / 50$ significantly increased the bulb growth index (Table 1). The size of flask should have influenced the gaseous components and the humidity of the microenvironment, affecting in vitro growth (Kozai et al., 1986); however, a previous experiment performed on Rhodophiala using 45, 120 and $350 \mathrm{~mL}$ flasks with the same volume of medium showed no differences in the growth index (Muñoz, 2006). In the present study, differences in the growth index could be attributed to the availability of nutrients because the concentrations of the nutrients $\mathrm{NH}_{4}, \mathrm{P}$, and $\mathrm{K}$ remaining in the medium were higher with the $350 / 50$ treatment than the $45 / 10$ treatment. It is also possible that this effect was due to the dilution of exudates because fewer browned explants were observed with a higher medium volume (Table 1).

When comparing liquid and gelled MS medium, after $60 \mathrm{~d}$ of in vitro cultivation, similar shoot development was achieved in the three Rhodophiala species. On the 


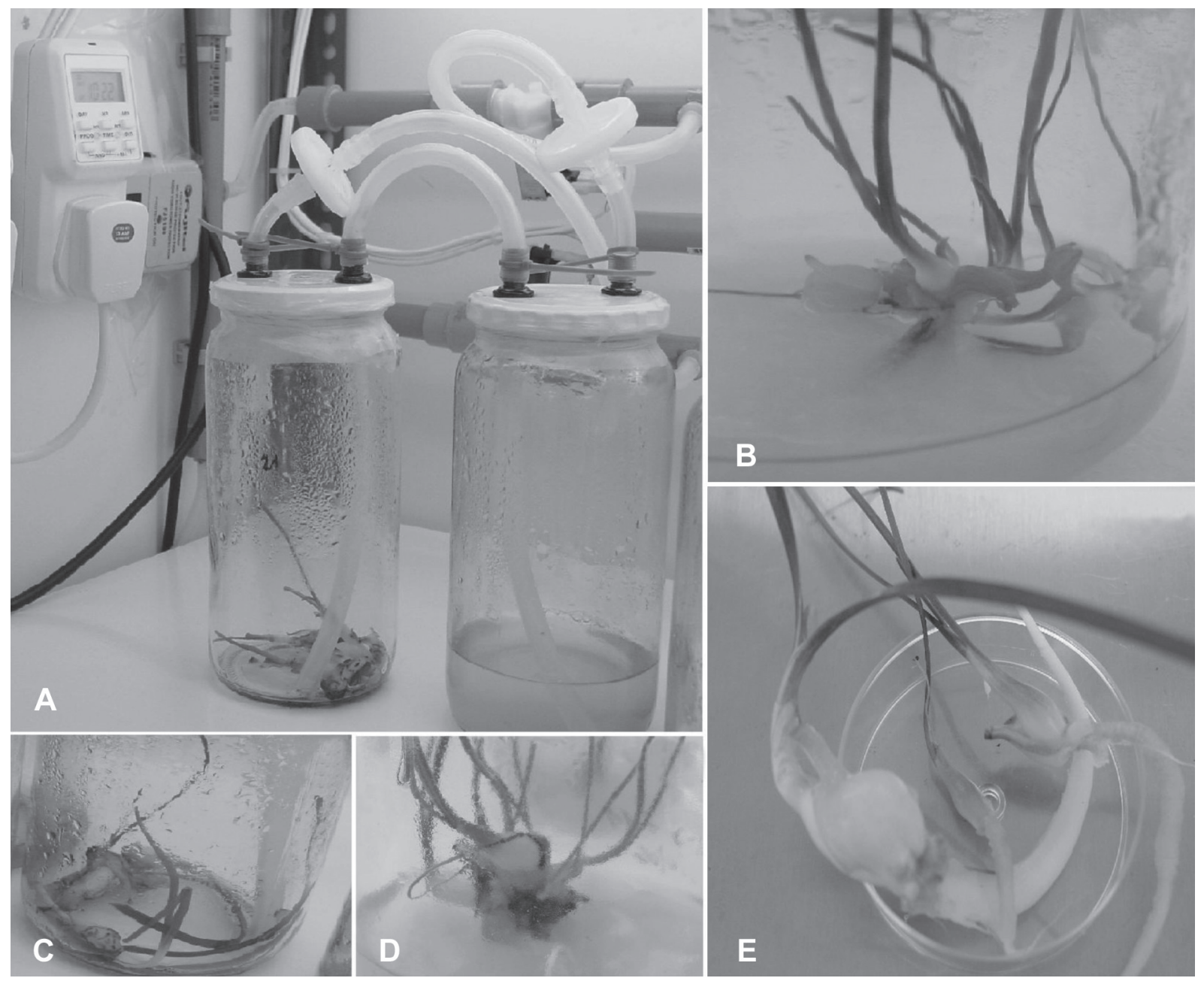

Figure 1. In vitro development of Rhodophiala species: A) Temporary immersion system (TIS) type "Twin flask" for Rhodophiala culture. B) Multiple shooting from single explant of $R$. montana cultured in liquid medium with cotton support. C) Details of explants visualization inside TIS unit. D) Multiple shooting from single explant of $R$. ananuca cultured in gelled medium. E) Small bulbs harvested from in vitro culture, ready to start acclimatization.

other hand, the bulb growth index was significantly higher in liquid culture system for $R$. montana and $R$. splendens. In all cases the DM percentage did not differ between treatments, but higher browning in $R$. ananuca and hyperhydricity in $R$. splendens and $R$. ananuca were observed in explants developed in liquid media (Table 2).

After three stages of acclimatization, the survival of in vitro grown plants using solid media was high (87-94\%), whereas for plants derived from liquid media survival was significantly lower (38\% for $R$. splendens and $R$. ananuca). In the Amaryllidaceae, successful acclimatization seems to be related to the weight of bulbs, even for plants coming from liquid medium cultures (Angulo et al., 2003). In our work, bulbs for acclimatization weighed between 0.16 and $3.8 \mathrm{~g}$ (Figure 1E), but there was no correlation between the in vitro bulb weight and the survival of plants coming from liquid media. However, in the three Rhodophiala species, all in vitro plants classified as hyperhydric died during acclimatization. Mortality could be related to the disruption of hydric regulation and transpiration. Plants from liquid medium cultures, probably well adapted to hydrophytic conditions, were severely affected by $e x$ vitro conditions; this effect was especially observed for $R$. splendens and $R$. ananuca.

Plants that survived the acclimatization process 


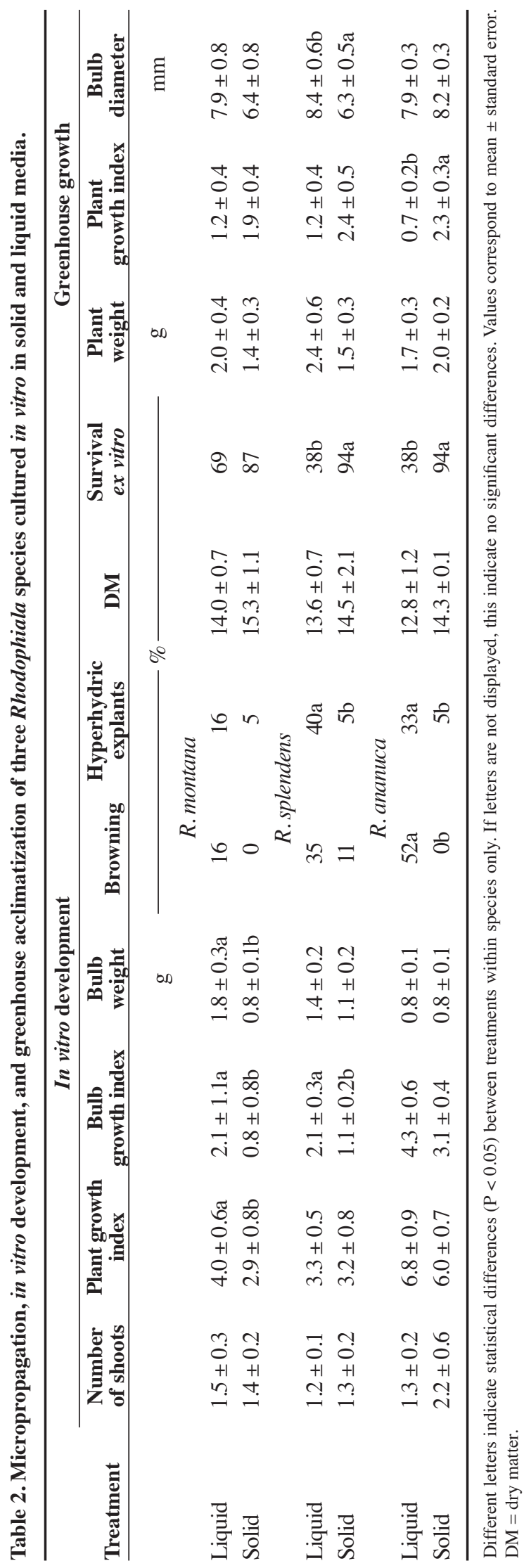

reached similar final weights (fresh biomass) independent of previous in vitro culture conditions (solid or liquid medium). Bulb weight achieved in vitro in liquid medium had no relationship $\left(\mathrm{P}=0.1 ; \mathrm{R}^{2}=3.6 \%\right)$ with the final plant weight after ex vitro culture, suggesting that in vitro fresh biomass is not a good predictor of survival and further ex vitro growth.

Only one temporary immersion treatment in $R$. ananuca produced more shoots than the liquid shaken medium (Table 3). In the rest of the treatments (TIS, static and gelled media treatments), the response of explants was similar for all species tested (Figure 1C). TIS has resulted in an important improvement in the micropropagation of potatoes (Solanum tuberosum L.), banana (Musa x paradisiaca L.) and yucca as reported by Etienne and Berthouly (2002), but results with bulbous plants have been moderately better or not different when compared to conventional tissue culture systems (e.g., Charybdis sp. and Hippeastrum $x$ chmielii) (Wawrosch et al., 2005; Ruffoni and Savona, 2005; Ilczuk et al., 2005).

\section{CONCLUSIONS}

When Rhodophiala microbulbs were cultivated in gelled media, multiplication rates were low, but in vitro plantlets normally grew with a high percentage of survival to acclimatization and adaptation to greenhouse conditions. It is possible to cultivate Rhodophiala in conventional liquid media if automation or lower cost process is desired, but additional efforts must be made to control hyperhydricity. Temporal immersion system appears to effectively control hyperhydricity, but it does not have a significant influence on plant propagation rate and in vitro bulb growth, compared with gelled medium. These bulbous species show moderate or none response to TIS, probably due to conservative patron of development that favors the growth of mother bulbs instead of daughter bulb initiation, behavior difficult to break, even using different systems that involve differences in microculture humidity, gaseous exchange and availability of medium components.

Current protocols for the micropropagation of Rhodophiala are not efficient enough for commercial purposes but could be used for ex situ conservation in germplasm banks.

\section{ACKNOWLEDGEMENTS}

This study was funded by Fondo de Innovación Agraria (FIA) Project BIOT-01-A-071. 
Table 3. Effect of temporary immersion systems (TIS), static liquid, shaken liquid, and gelled MS media on shoot number and growth of Rhodophiala microbulbs.

\begin{tabular}{|c|c|c|c|c|c|}
\hline Treatment & $\begin{array}{c}\text { Number } \\
\text { of shoots }\end{array}$ & $\begin{array}{c}\text { Plant growth } \\
\text { index }\end{array}$ & Bulb growth index & Browning & Hyperhydricity \\
\hline & & & & & $\%$ \\
\hline \multicolumn{6}{|c|}{ R. splendens } \\
\hline TIS 20 & $1.3 \pm 0.2$ & $0.22 \pm 0.05$ & $0.13 \pm 0.03$ & $35 \pm 24$ & $4 \pm 4 a$ \\
\hline TIS 40 & $1.1 \pm 0.1$ & $0.24 \pm 0.02$ & $0.18 \pm 0.01$ & $63 \pm 9$ & $24 \pm 13 \mathrm{ab}$ \\
\hline TIS 60 & $1.2 \pm 0.1$ & $0.22 \pm 0.09$ & $0.16 \pm 0.07$ & $43 \pm 23$ & $38 \pm 12 \mathrm{ab}$ \\
\hline Static liquid & $1.1 \pm 0.1$ & $0.27 \pm 0.09$ & $0.17 \pm 0.05$ & $31 \pm 6$ & $63 \pm 9 b$ \\
\hline Shaken liquid & $1.1 \pm 0.1$ & $0.33 \pm 0.3$ & $0.28 \pm 0.30$ & $29 \pm 20$ & $62 \pm 2 b$ \\
\hline Gelled & $1.0 \pm 0.0$ & $0.12 \pm 0.01$ & $0.08 \pm 0.00$ & $66 \pm 18$ & $7 \pm 4 a$ \\
\hline \multicolumn{6}{|c|}{ R. montana } \\
\hline TIS 20 & $1.06 \pm 0.1$ & $0.06 \pm 0.05$ & $0.04 \pm 0.03$ & $40 \pm 6$ & $18 \pm 10 \mathrm{a}$ \\
\hline TIS 40 & $1.06 \pm 0.1$ & $0.16 \pm 0.05$ & $0.12 \pm 0.03$ & $23 \pm 13$ & $17 \pm 17 \mathrm{a}$ \\
\hline TIS 60 & $1.30 \pm 0.2$ & $0.14 \pm 0.07$ & $0.06 \pm 0.03$ & $27 \pm 2$ & $0 \pm 0 \mathrm{a}$ \\
\hline Static liquid & $1.00 \pm 0.0$ & $0.08 \pm 0.01$ & $0.02 \pm 0.01$ & $27 \pm 4$ & $13 \pm 7 \mathrm{a}$ \\
\hline Gelled & $1.20 \pm 0.1$ & $0.02 \pm 0.03$ & $-0.02 \pm 0.02$ & $22 \pm 5$ & $18 \pm 12 \mathrm{a}$ \\
\hline \multicolumn{6}{|c|}{ R. ananuca } \\
\hline TIS 20 & $1.9 \pm 0.2 \mathrm{a}$ & $0.38 \pm 0.20$ & $0.22 \pm 0.10$ & $6 \pm 3$ & $12 \pm 12 \mathrm{a}$ \\
\hline TIS 40 & $1.1 \pm 0.1 \mathrm{ab}$ & $0.20 \pm 0.10$ & $0.16 \pm 0.09$ & $7 \pm 4$ & $25 \pm 8 \mathrm{a}$ \\
\hline TIS 60 & $1.3 \pm 0.1 \mathrm{ab}$ & $0.30 \pm 0.06$ & $0.20 \pm 0.08$ & $8 \pm 4$ & $19 \pm 13 a$ \\
\hline Static liquid & $1.6 \pm 0.2 \mathrm{ab}$ & $0.52 \pm 0.30$ & $0.18 \pm 0.10$ & $8 \pm 2$ & $8 \pm 4 a$ \\
\hline Shaken liquid & $1.0 \pm 0.0 \mathrm{~b}$ & $0.12 \pm 0.05$ & $0.10 \pm 0.06$ & $0 \pm 0$ & $93 \pm 7 b$ \\
\hline Gelled & $1.6 \pm 0.2 \mathrm{ab}$ & $0.12 \pm 0.03$ & $0.04 \pm 0.01$ & $8 \pm 2$ & $4 \pm 4 a$ \\
\hline
\end{tabular}

Different letters indicate statistical differences $(\mathrm{P}<0.05)$ between treatments within species only. If letters are not displayed, this indicate no significant differences. Values correspond to mean \pm standard error.

TIS: temporary immersion system; TIS 20, TIS 40 and TIS 60 mean 20, 40 and $60 \mathrm{~mL}$ per explant, respectively.

\section{RESUMEN}

Influencia del tipo del recipiente, estado físico del medio e inmersión temporal en la micropropagación de tres especies de Rhodophiala. Rhodophiala C. Presl (Amaryllidaceae) es un género de geófitas nativas de Sudamérica con un gran potencial ornamental por sus atractivas flores. La mayoría de las especies de este género son poco conocidas y tienen problemas de conservación. El objetivo de este estudio fue optimizar un proceso de micropropagación para sustentar el uso y preservación de tres especies nativas de Chile: $R$. montana (Phil.) Traub, $R$. splendens (Rengifo) Traub y $R$. ananuca (Phil.) Traub. Se evaluó la factibilidad de la implementación del cultivo en medio líquido y se determinó la influencia de diferentes sistemas de cultivo in vitro en la formación de brotes e incremento en biomasa de microbulbillos. Se ejecutaron tres experimentos. El primero determinó la influencia del tamaño del frasco y el volumen de medio Murashige y Skoog (MS), el segundo comparó medio MS líquido y sólido, y el tercero comparó un sistema de inmersión temporal (SIT), líquido estático, líquido en agitación y medio MS gelificado. Con frascos de $350 \mathrm{~mL}$ con volumen de medio de $50 \mathrm{~mL}$ se obtuvo un $100 \%$ de mayor peso fresco de bulbo que en frascos de $45 \mathrm{~mL}$ con volumen de medio de $10 \mathrm{~mL}$. En medios gelificados, la hiperhidricidad afectó al 5\% de los explantes, mientras que en medio líquido fue $16-40 \%$. La supervivencia a la aclimatación alcanzó un $87-94 \%$ para plantas provenientes de medio gelificado; para las provenientes de medio líquido llegó a $38-69 \%$. SIT permitió obtener mayor tasa de propagación ( 1,9 brotes en 30 días), comparado con medio líquido en agitación $(1,0$ brote $)(\mathrm{P}<0,05)$ en $R$. ananuca. Los procedimientos presentados son apropiados para la conservación ex situ y el establecimiento de bancos de germoplasma.

Palabras clave: SIT, cultivo en medio líquido, micropropagación, aclimatación, Rhodophiala. 


\section{LITERATURE CITED}

Adelberg, J. 2004. SIVB 2003 Congress Symposium Proceeding: Plant growth and sugar utilization in an agitated, thin-film liquid system for micropropagation . In Vitro Cell. Dev. Biol. - Plant 40:245-250.

Angulo, M., R. Colque, F. Viladomat, J. Bastida, and C. Codina. 2003. In vitro production of bulblets of Cyrtanthus loddigesianus and Cyrtanthus speciosus. J. Hort. Sci. Biotech. 78:441-446.

Etienne, H., and M. Berthouly. 2002. Temporary immersion systems in plant micropropagation. Plant Cell Tiss. Organ Cult. 69:215-231.

Ilczuk, A., T. Winkelmann, S. Richartz, M. Witomska, and M. Serek. 2005. In vitro propagation of Hippeastrum $x$ chmielli Chm. - influence of flurprimidol and the culture in solid or liquid medium and in temporary immersion systems. Plant Cell Tiss. Organ Cult. 83:339-346.

Jara, G., P. Seemann, M. Muñoz, R. Riegel, F. Schiappacasse, P. Peñailillo, y A. Basoalto. 2005. Estudios realizados en torno al cultivo de tejidos en Rhodophiala. p. 59-61. In Seemann, P., G. Jara, I. Castro, and M. Muñoz (eds.) Avances en horticultura ornamental. Primer Simposio de Horticultura Ornamental, Valdivia, Chile. 29-30 de septiembre de 2005.

Kozai,T.,F.Kazuhiro, and I.Watanabe. 1986. Fundamental studies on environments in plant tissue culture vessels. Effects of stoppers and vessels on gas exchange rates between inside an outside of vessels closed with stoppers. p. 18. In Jeong, B.R. (ed.) Collected papers on environmental control in micropropagation. Vol. 1. Chiba University, Chiba, Japan.

McClelland, M.T., and M.A.L. Smith. 1990. Vessel type, closure, and explant orientation influence in vitro performance of five woody species. HortScience 25:797-800.
Murashige, T., and F. Skoog. 1962. A revised medium for rapid growth and bioassays with tobacco tissues cultures. Physiol. Plant. 15:473-479.

Muñoz, M. 2006. Estudio de sistemas de cultivo in vitro, aclimatización de plántulas y crecimiento de bulbos en tres especies de Rhodophiala Presl (Amaryllidaceae). 117 p. Tesis. Mg. Sc. Universidad Austral de Chile, Facultad de Ciencias Agrarias, Valdivia, Chile.

Olate, E., and M. Bridgen. 2005. Techniques for the in vitro propagation of Rhodophiala and Leucocoryne spp. Acta Hort. (ISHS) 673:335-339.

Ruffoni, B., and M. Savona. 2005. The temporary immersion system (TIS) for the improvement of micropropagation of ornamental plants. Acta Hort. (ISHS) 683:445-453.

Schiappacasse, F., P. Peñailillo, and P. Yánez. 2002. Propagación de bulbosas chilenas ornamentales. 65 p. Editorial Universidad de Talca, Talca, Chile.

Traub, H. 1956. The genera Rhodophiala Presl and Phycella Lindl.: Key to the species and synonymy. Plant Life (Herbertia) 12:67-76.

Wawrosch, C., A. Kongbangkerd, A. Köpf, and B. Kopp. 2005. Shoot regeneration from nodules of Charybdis sp.: A comparison of semisolid, liquid and temporary immersion culture systems. Plant Cell Tiss. Organ Cult. 81:319-322.

Zhu, L., X. Yuan, and M. Welander. 2005. Optimization of growing conditions for the apple rootstock M26 grown in RITA containers using temporary immersion principle. Plant Cell Tiss. Organ Cult. 81:313-318.

Ziv, M. 2005. Simple bioreactors for mass propagation of plants. Plant Cell Tiss. Organ Cult. 81:277-285. 